\title{
Rural education: Reimagining the role of the church in transforming poverty in South Africa
}

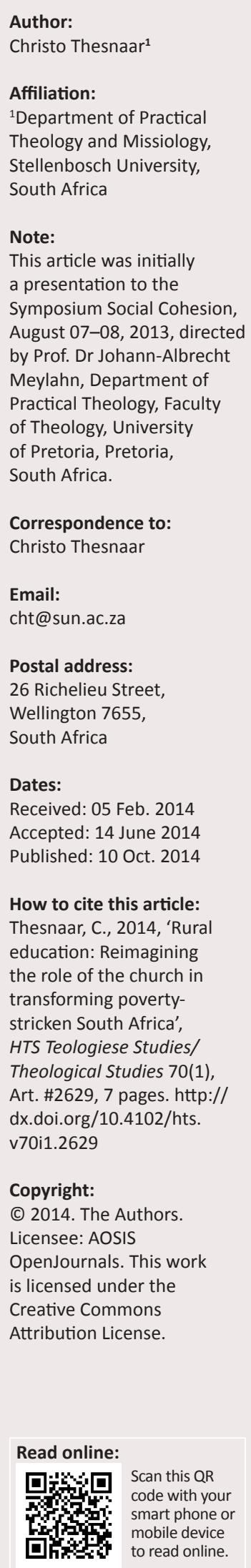

The desire to remember the plight of the poor in South Africa has reduced in the last 20 years after the transition from apartheid to freedom. To a large extent, Faith Based Organizations (FBOs) and the religious society at large have lost their 'dangerous memory' which keeps us mindful of those who suffered and whose plight is usually forgotten or suppressed. In this contribution the conditions of poor farm school children in multigrade rural education will be scrutinised by unpacking the contextual factors that cause us to forget their plight. This article will seek to reimagine the role of the church in poverty-stricken South Africa by engaging with the work of Talcott Parsons, the practical theologian Johannes A. Van der Ven, as well as the work of the political theologian Johann Baptist Metz in order to affirm the focus of Practical Theology to transform society and to contribute to the quest for justice and liberation for the poor in rural education. This reimagining discourse has a fundamental responsibility to challenge the social, political and economic realities that shape the lives of human beings within rural education, remembering the plight of the poor, and participating on their journey towards liberation and healing. It is proposed that if the church can activate its 'dangerous memory' it will be able to reimagine its role by transforming our povertystricken South African society, open new avenues for breaking the cycle of poverty and contribute to rural education.

\section{Introduction}

In October 2012, the Minister of Education in the Western Cape, Donald Grant, decided to close 17 rural schools, ${ }^{1}$ mostly situated in extreme poverty-burdened areas. He based this decision on the premise that the learners in these schools would receive 'better education opportunities' in larger urban schools. The critical concern of this decision was that it was made in a unilateral way with very little consultation with the local school bodies, staff, community and other role players. It was therefore largely expected that the teachers, school bodies, parents, the community and academics resisted the closure of these schools. It was also clear that discussions with the minister to urge him to change his decision were futile. This left the interest groups with no choice but to challenge this unilateral decision in a court of law.

On the 1st of August 2013, after a painful court battle, the Western Cape High Court set aside the Education MEC Grant's decision to close 17 schools. Although the various stakeholders were elated with this decision, Grant called it a 'sad day for education' and referred to the ruling, saying that it 'compromised the education opportunities for the learners at the 17 schools' (Die Burger 31 July 2013:1). He made this statement based on the assumption that learners from these 17 schools would receive better education opportunities in larger schools. This is however in contrast to the research done by Ruzive (2012:65) which argued against a 'one size fits all' policy for rural education in South Africa.

These deliberations raise disconcerting questions regarding the complex issues of poverty, rural education, social cohesion and ultimately transformation and reconciliation, as well as the role of the church within the public domain, such as: Why would provincial departments still make unilateral decisions in a democratic country given our history? Why would a department not engage with the designated role players and stakeholders to ensure that sustainable education processes could be developed? If many of the school buildings of these schools (those under discussion) belong to the church, then what is the role and responsibility of the church (different forms) in this regard? Should the church just keep to its own sphere of life and accept that this is an educational problem?

\footnotetext{
The schools are mostly the so-called multigrade schools. Multigrade teaching, which has been practiced in both developed and developing countries has shown success with adequate support and is one of the major alternatives (Hargreaves 2005). Multigrade teaching is a pedagogic approach to increase access and retention, while improving quality education, a strategy to address teacher shortages, particularly in small and remote schools (Juvane 2007) and it is associated with 'small' schools in remote and sparsely populated areas where there may be only one, two or three teachers who offer a complete cycle of primary education (Joubert 2010:59). By bringing the school closer to the community, they encourage more children to attend school. Within the Western Cape more than 335 schools, 876 teachers and about 25437 learners fall into this category (Jordaan \& Joubert n.d.:6).
} 
It seems there are no clear-cut simplistic answers, and no cheap explanations for this complex but critical situation. However, for this article to make a contribution to the abovementioned complex reality, it will engage on a methodological level, with the sociologist Talcott Parsons (1965), the practical theologian Johannes A. Van der Ven (1993), as well as the work of the political theologian Johann Baptist Metz (1980), in order to identify meaningful ways in which the religious society (in particular the church) can deal with the challenges of rural education.

\section{Core functions of the Church}

The sociologist, Talcott Parsons (1965), is well known for his theoretical theory on society and social institutions. In his engagement with difficult and complex realities in our society he contemplated whether one should begin by dealing with the individual actors in the institutions or with the institution itself when addressing complex issues. He based his thinking on the well-known notion that individuals do not live alone in this world, and therefore their actions always happen through interactions with others. These interactions between individuals always take place within any social institution. In this context, he came to the conclusion that the actions of individuals do not just take place during interactions with others, as well as within social institutions, but are in themselves subject to institutionalism. Institutionalism, according to Parsons (1965:30-79), represents the actions and interactions of people characterised by certain regularities. People normally take action according to specific conditions and patterns when they need to engage with others or society. The key question would be to understand where these patterns come from? According to Parsons (1965:30-79) these patterns emanate from how the actors position themselves within the social institution and the role they play within the institution. These roles are formed by certain norms embedded within the culture, surrounded by the social institutions they act upon.

Within this context, Parsons noticed that people struggle with problems in their daily lives that they attempt to solve. $\mathrm{He}$ identified four groups of problems: (1) what do our beliefs, values and norms entail? This question leads to what Parsons (1965:30-79) calls 'latency' (L), meaning that it stays latent (i.e. under the surface) until a crisis occurs. When the crisis transpires, then the beliefs, values and norms are suddenly activated and proceed to play an imperative role. According to Van der Ven (1993:70), latency can also be described as the cultural life of a group. (2) What keeps us together in a social sense and what distance and nearness do we keep towards each other? This, he calls 'integration' (I), because it is about the cohesion and binding power of the group. Integration is essentially about the social life of people (Van der Ven 1993:70). (3) What are the actions we want to take? This he calls 'goal attainment' (G). It is about what people want to pursue and how to achieve it. Attainment refers to the political life of people (Van der Ven 1993:70). (4) How do we acquire the necessary staff and finances? This question leads to what Parsons calls, 'adaptation' (A). Adaptation is about the ability of a person to adapt to the group or society they function or live in. Can they, for example, manage to get the necessary material and financial resources together to adapt to the group and society they live in? In this sense, one could say that adaptation represents the economic life of people (Van der Ven 1993:70). From these four problems the LIGA model was developed (Van der Ven 1993:71).

The LIGA model could be understood as a structured directed movement from the top to the bottom - from legacy, to integration, to goal attainment, and then to adaptation. This movement could also be described as a movement from the cultural life to the social life, from the social life to the political life and from the political life to the economic life. This model could also be read as a conditioning movement from the bottom up AGIL - from adaptation, to goal attainment, to integration and then to legacy (Van der Ven 1993:71). In this movement, the political life is conditioned by the economic life, the social life by the political and the cultural by the social life. The implication of conditioning is that if the conditions at the lower level are not met the next level cannot be reached.

Parsons (1965:30-79) further saw a connection between some of the dimensions of the model. Firstly, he saw a clear connection between latency and integration due to the fact that he saw them both as structured with the focus of keeping the group together. According to him, people allow themselves to be led by their convictions, values and norms, as well as through their emotions and attitudes. People function from a value system and from their feelings. On these grounds, Parsons (1965 cited in Van der Ven 1993:72) calls this normative, as well as expressive rationality, and therefore structural. Secondly, he describes goal attainment and adaptation as functional. The goal is to keep the relations with the outside world and the environment intact. People constantly mediate between the group and the environment. They need to develop goals in order to be sustainable and to survive in the world in which they live. Based on this link between the structural and the functional the model is then called 'structural functionalism'. According to Van der Ven (1993:71), Parsons makes a third link between legacy and goal attainment. This should be understood as a dialectic relation. On the one hand, it is about the influence that values and norms (legacy) have on the programmes and projects during the attainment of goals, and on the other hand, these form the conditions on which the beliefs, values and norms should be realised.

Van der Ven (1993:78) interprets and adapts Parsons's LIGA model for the church context, without changing the theory underpinning the model in his quest to discuss the core functions of the church. He substitutes legacy with identity as the first core function of the church. Identity has to do with the convictions, values and norms of the church and therefore the church can no longer be seen as latent or 
sleeping. Secondly, Van der Ven (1993:78) keeps the term 'integration' after debating whether or not it should be substituted with 'unity'. For him, it is about the reference to the cohesion, uniformity and plurality of the church. Thirdly, he translates goal attainment with policy - such as church policies, programmes and project development. Lastly, he substitutes adaptation with control. With the concept of control, he refers to the personal and financial conditions as well as the resources of the church.

With reference to the discussion on the core functions, the church is, in terms of its latency within the society, primarily positioned within the dimension of cultural life. Although it is placed within the cultural life it still has a clear obligation to engage with the social, political and economic life. Van der Ven (1993:80) explains that an ecclesiology should develop from the cultural life of the society to the other dimensions without excluding one of the dimensions.

For the church to actively engage with all the dimensions of our society, it should be realised that the contextual relations within a society simultaneously pose boundaries and possibilities, dangers and opportunities, threats and challenges for the church. Within our current context, secularism should be understood as a boundary and a possibility for our identity. In our modern society, individualism should be seen as a danger and an opportunity for integration and community. Utilisation is a threat and a challenge for policies and strategies within the political system, and calculation of the finances and resources becomes a possible loss and gain for control. Despite these realities, the church should continue to engage actively with society on the grounds that the core functions are actually enshrined in the goals of the church.

\section{Dangerous memory and Church identity}

A theology that takes the Christian faith and the tradition of the church seriously will essentially need to be contextual. In this regard, Parsons's model (as interpreted by Van der Ven) proves useful as it challenges the church and theology within the South African context to re-establish its identity. With a clear identity, the church and theology can and should be the key drivers in the integration of the people into our social society, given the apartheid past. This is deeply embedded in its ministry of reconciliation, not only between God and us but also reconciling people with one another. Therefore, the church needs to actively pursue the transformation of our society, including challenging the policies of the political domain, as well as control issues in the economic domain. In this sense, ' $[n]$ o such theological theory can allow any abstraction from such problems as public life, justice and freedom, in other words, political problems' (Metz 1980:88).

This is indeed a challenge in the Southern region, more specifically Africa, because it challenges Christian theology, identity, spirituality and the ability of Christians to transform the challenges that people are facing in the society in which they live. In this sense, the German political theologian Johann Baptist Metz has articulated an approach to Christian spirituality that emphasises the central place and role of memory in our human experience and spirituality. According to him all human experiences, all spiritualities, are grounded in the narratives of memories. As he states in Faith in history and society, memory is indeed what gives human beings, both as individuals and as communities, their historical identity: 'Identity is formed when memories are aroused' (Metz 1980:66). With this in mind, Metz (1980:171) reminds us of another kind of memory, which he calls 'dangerous memory'. He describes dangerous memory as a type of memory that shocks us out of our comfort zones that which we perceive as familiar in order to acknowledge the reality of human suffering. When the church can embrace this and acknowledge it as central to its identity, it will be able to engage with and reveal new and 'dangerous' insights in the present and future life.

The revelation of these dangerous insights in the present is revolutionary because they 'illuminate for a few moments and with a harsh and steady light the questionable nature of things we have apparently come to terms with' (Metz 1980:109). For the church and theology, the memory of suffering is particularly dangerous as these memories are not simply a matter of looking backward at the promises of God in the Old and New Testament, but they are indeed present and future-oriented. Past memories, in which we remember the promises made by God and the hope based on these promises, has everything to do with the present and the future. Memories of human suffering 'make demands on us' (Metz 1980:109) and therefore 'make the present unsafe' by 'break[ing] through the grip of the prevailing consciousness' of the present in light of unfulfilled hopes (Metz 1980:200). These memories interrupt us and shock us. Consequently, the present needs to be radically challenged in light of the future promised by God. Poverty and rural education is such an area in our society that needs to be radically challenged in light of the future promises of God.

\section{Poverty and rural education}

Poverty knows no boundaries. It affects the young and the old, the healthy and the ill, woman, men and, in particular, rural children in our societies on which it has a devastating impact. Ramphele and Wilson (1989) indicate that:

Poverty is like illness. It shows itself in different ways in different historical situations, and it has diverse causes. To be poor doesn't only mean to have little or no money, but far more. (p. 7)

Rural people and rural women in particular, bear the largest burden of poverty in South Africa. Poverty must be understood as multifaceted (Lukhele-Olorunju 2012:103). It can be particularly linked to hunger, unemployment, exploitation and lack of access to clean water, sanitation, health care or schools. But it is also deeply about vulnerability, the crisis poor people are in and homelessness. In this sense, 
poor families in rural areas move homes twice as often, get evicted five times as much (Hamunyela 2008:167). With these realities about poverty in mind it remains difficult to envisage the full impact of poverty on school children in rural areas. These children often do not eat well. Research has shown that students who are hungry are more likely to become distracted from learning (see Joubert [2010:58-62] in this regard). However, what is alarming is when these learners get older poverty has a cumulative impact on their evolving capacities with an increasing likelihood that their lives will be scarred by educational underachievement, poor health, low employment opportunities and long-term welfare dependence (Archambault et al. 2009:413).

A further illustration of the multifaceted reality of poverty is the occurrence of Fetal Alcohol Syndrome (FAS) within rural communities in the Western Cape. Research conducted by the universities of Cape Town, Stellenbosch and New Mexico in the areas of Wellington, Bonnievale, Robertson, Ashton and Montagu indicated in their preliminary findings that the Western Cape still has the highest incidence of FAS worldwide (Carr 2013:1). This study further indicated that the researchers found a prevalence of the FAS of between 61 and 94 per 1000 children in the Wellington area (Lewis 2011). Added to poverty and the existence of FAS is the illiteracy of the parents in farming communities. Studies have shown that often their parents talk less and may also speak more incorrectly, that is, poor grammar usage (see Department of Education [n.d.]; Eccles \& Davis-Kean 2005; Lagina 2002; Walker [n.d]). They do not ask their children as many questions and neither do they in turn encourage them to ask questions. Both parents are in the labour force and children are left unsupervised after school and during summer vacations. These students learn their conduct from their peers, and often this conduct is not appropriate for a classroom. In this regard, poor children have more contact with aggressive peers (Schore 2002:464), and experience more community violence due to unsafe home neighbourhoods, which can hurt academic performance (Fuller 2008:178). Rural schools are mostly seen as the forgotten schools, and therefore their efficiency is subject to challenges as regards facilities, teachers, education, curriculum support, teacher support, and parent involvement, et cetera. These schools also lack after-school opportunities, and therefore they do not benefit from the positive effects those can have on their academic success, social behaviour, and the opportunities for enrichment they provide. The physical teaching facilities of rural schools in the Western Cape are a big challenge in these schools, as neither the owners (in most cases churches such as the Uniting Reformed Church of Southern Africa [URCSA] or the Dutch Reformed Church [DRC]), nor the Education Department, do much to improve their facilities. In many instances, the buildings are in a poor state, and mostly too small to accommodate the number of children from the designated area of intake. They also generally lack the basic sporting and other recreational facilities.
In addition, these children are also usually less healthy, ${ }^{2}$ their language skills are less developed (a factor that has a negative influence on their school achievement), and they are generally less well equipped - socially, emotionally and physically - to undertake a school programme (Hooghoff \& Joubert 2010:45). According to the Centre for Multi-grade Education, multigrade teaching is used in approximately 7000 South African schools. Most of these schools are located in rural areas (Boonzaaier 2009:9-10). This is the sad reality for $30 \%$ of all primary schools in South Africa, affecting nearly 3 million of our country's children. They will never be able to compete on par, they will never get close to a tertiary education, nor will they ever become part of the economy. Eighty per cent will drop out before they reach Grade 12. They are being educated to perpetuate the same illiteracy and lack of skills that confined their parents to lifelong poverty (Boonzaaier 2009). In terms of the schools in the Wellington area that are classified as multigrade schools and had to face closure, about $10 \%$ of the learners will stay in school up to Grade 10, and 10\% of them will complete Grade 12 successfully. It is clear that particularly disadvantaged learners in rural schools are probably not sufficiently prepared for the challenges and opportunities of the future. It is widely accepted that education is a significant means of contributing to breaking the cycle of poverty from one generation to the next. However, without a multidisciplinary approach to deal with this problem, it will not be possible. For many generations, rural school learners have been stuck in the chains as labourers on farms. Very few have managed to escape from it.

\section{How should the Church respond?}

Four cardinal questions now need to be asked. Firstly: Is the church at all disturbed by the poverty-stricken context of rural education in the Western Cape? Secondly: Does the poverty-stricken context of rural education in the Western Cape manage to disrupt us in such a way that it challenges and questions our boundaries? Thirdly: Has the church, perhaps, been overwhelmed and disabled by what former President Nelson Mandela said when he averred that one can smell poverty when one visits many parts of rural South Africa? Finally: Has the church and theology given up on the poor and rural people in the forgotten schools?

Based on the discussion thus far, the church should be challenged by Metz's plea (1980:200) that the Christian faith

2.'Poverty is a major risk factor for children's environmental health. It operates in three main ways. Firstly, because of what has been termed environmental injustice, there is a marked tendency for the poorest in society to be more exposed to there is a marked tendency for the poorest in society to be more exposed to
environmental hazards. This occurs both because the poor are more likely to live in environmental hazards. This occurs both because the poor are more likely to live in
inadequate housing, in more hazardous areas, and because there is a tendency for polluting industries and other activities to congregate in poorer areas (e.g. because of lower land prices, less strict regulations and less effective opposition from the communities involved' (Terreblanche 2002:181-182). Secondly, 'poverty tends to be associated with more harmful (or less self-protective) lifestyles and behaviours, for example in terms of diet, smoking, exercise and drug usage, both because of lack of awareness of the risks concerned and the lack of resources to avoid them' (McLoyd 1990:336). Thirdly, 'poverty makes it harder for those at risk to obtain treatment or help, often because of their remoteness from the necessary services, their lack of help, often because of their remoteness from the necessary services, their lack of resources to access them and - in some cases - inherent biases and inadequacies within the services themselves. As a result, almost all environmental health effects show strong associations with poverty. It seems that poverty represents an important, complex and interrelated set of social and environmental risks that cannot easily be specified separately. It also acts as an important confounder and modifier of relationships between many other risk factors and human health (Terreblanche 2002:150-160) 
should be viewed as the narration of a particular memory (such as the predicament of the rural education), and the dangerous memory of the death and resurrection of Jesus Christ, which has broken through the world's assumptions about political power, policies, economic gains and violence, and opened our eyes to the suffering of others (particularly in the case of the innocent, such as rural school children). The church has always been a political and social reality. Therefore, the task of the church is to carry out the same task that Christian theology has always carried out, namely to speak about God by making the connection between the Christian message and the modern world visible and by expressing the Christian tradition in this world as a dangerous memory (Metz 1980:89). To adhere to this call and task the church should regain its identity as emphasised by the theories of Parsons and Van der Ven (1993). Regaining identity has to do with the rediscovery of the fundamental truths of the Christian faith, and to live the fundamental truths in the world via our values and norms. The church should continuously commit itself to be hermeneutists in order to take into account the fact that historical and social differences repeatedly raise the question as to what the content and the attentions of the biblical testimony really are. In this sense, political 'theology' is not a simple theory of the subsequent application of the Christian message, but a theory of the truth of that message with a practical and critical intention for the modern world (Metz 1980:89).

As true hermeneutists with a clear identity, the Church is the public witness and bearer of the 'dangerous' memory for the victims of history. The church and its ministry should allow themselves to be 'interrupted' by the memory of human suffering, as well as the current suffering which challenges the status quo and widens the horizons of our imagination, drawing us into deeper consciousness of, and compassion for, the victims of suffering. This becomes possible when the church starts to listen to the suffering, poverty and oppression of the forgotten schools, and truly listens to the Word of Christ and what it requires in order for us to deal with the plea of the poor rural school children and their families. It is about a willingness to suffer with the suffering of children and families in rural education.

A Christian theology and spirituality (identity) that places dangerous memory of human suffering at its centre will obviously have radical consequences as far as the integration with the social sector is concerned. In other words, the church and congregations as living communities should operate as living bodies that work to relieve the suffering of others. The 'praxis' of memory takes shape when Christians commit, in solidarity with the victims of violence, to overcome the suffering caused by oppression and injustice in light of the promises of God (Metz 1980:229). The solidarity Metz calls for, is not to be confused with mere sympathy (Metz 1980:230), nor is it the false solidarity of our 'exchange society' that is 'based on an alliance between equal partners' whose purpose is 'mutual success and progress,' or looking after each other's interests as long as there is 'something in it for me' (Metz 1980:231). Authentic Christian solidarity is radically universal:

It extends to those who have been overcome and left behind in the march of progress. It includes the dead. Indeed, the theological category of solidarity reveals its mystical and universal aspect above all in its memory of solidarity with the dead. (p. 231)

Only with a 'world-wide perspective' can 'solidarity acquires [sic] its full dimension' (Metz 1980:234).

On a personal and individual level (individual responsibility of the church), this radical solidarity requires a constant openness to personal transformation and a 'willingness to suffer the sufferings of others', the literal meaning of compassion (Metz 1980:95). It also means that, in resistance to the narrow solidarity of the 'society of exchange', that treats persons outside of our horizon of concern as 'an anonymous mass', Christians will come to 'have a conscience not only about what they do or do not do to others, but also about what they let happen to others' (Metz 1980:95). After research into the rural schools of the Northern Cape, Waghid (2002:4) concluded that the personal dimension of a community should coexist with the functional. For him, the key is that the personal dimension of a community should resonate with notions such as confidence, courage, trust and the willingness of educators, learners and parents to sustain cooperative, mutual relations for purposes of enriching educational development. Although he does not include the church in his reference to the community, its role is embedded in the values of the church (identity), its congregants, and the role it plays in the community, as well as in its commitment to the outcome and purpose of enriching educational development.

On a political and economic level, (functional) solidarity with those who suffer means a radical questioning of the structures of socio-political power that are usually taken for granted:

[I]n light of the Christian memory of suffering, it is clear that social power and political domination ... continually have to justify themselves in view of actual suffering. The social and political power of the rich and the rulers must be open to the question of the extent to which it causes suffering. (Metz 1980:115)

As argued, the church should engage in the social, political and economic sphere with a clear identity to address the suffering of those who suffer. However, Waghid (2002:4) warns that when the functional gains priority over the personal then disunity, conflict and an insubstantial disengagement from developments in the community would feature prominently, thus undermining any coexistence of the personal and functional dimensions of the community. The church should therefore make sure how it should be playing its role as part of civil society when engaging with and addressing the needs of those who suffer, with a theology of wisdom embedded within a hermeneutical approach. This will assist the church to contribute to the eradication of imbalances in a constructive way. 
An authentic Christian spirituality creates an everdeepening solidarity with victims of suffering because of our emphasis on an eschatological hope in the promises of God (Louw 2008:237). The resurrection of Christ is one promise that in particular brings hope and meaning in suffering. It is from this perspective of hope, based on the promises of God, that the church needs to address the imbalances by restoring the dignity of the rural communities, reconciling with the brothers and sisters of these communities and engaging in a process of transformative justice in order to adhere to the calling of the church to education.

There are no quick solutions for providing education to the rural poor. The church should therefore not try to address this challenging reality in isolation. It needs to engage in a transdisciplinary process with other disciplines. There needs to be a combined effort to link schools with the community that will enable teachers to improve the quality and relevance of the education they are providing. The church should contribute to the strategies for quality education, as indicated by Van der Merwe (2011:784), in order to ensure that learners are: exposed to enriching events; exposed to high moral values; ensured of their teachers' presence as a prominent and stable aspect of their daily lives; enabled to master knowledge and skills to prepare them for social and economic mobility with sensitivity for diversity; and are conscientised in terms of their societal responsibility. This requires a long-term effort and commitment, with concerted action at the local, national and international level. In other words, the church needs to engage with various other networks of Christian commitments in order to unite against the predicament of the children in rural schools. On the local level, the church needs to be clear about their identity in order to have what Neil (2011:129) refers to as the self-confidence of believers, greater relevance for believers for their living in the 21st century, and a more confident voice emanating from the church which might even encourage society to take notice that the church has something to say. It requires the congregants who have the skills to assist rural children in schools (either in teaching or assisting to create a teaching environment) to go out with confidence, and to live and embody their God-given calling to assist suffering rural children in obtaining an education.

\section{Conclusion}

According to Article 27 of the Convention on the Rights of the Child (UNISEF n.d.), every child has the right to a standard of living that is adequate for the child's physical, mental, spiritual, moral and social development. Parents and those responsible for the child should obtain any help possible to implement this right. If there is a need, material assistance and support programmes should be provided, particularly with regard to nutrition, clothing and housing. This raises the question: What is the role of the church in adhering to the rights of the child?

When reflecting on the role of the church and its calling to suffering communities within rural education, the question that arises, is: 'Who is the "church"?' The theologian Dirkie
Smit (2004:352-360) reflected on the role of the church in the social challenges of our society and indicated that the church in all its forms, in prayer and worship, as living communities, as bigger bodies like circuits and synods, embedded in various other networks of Christian commitments, as active disciples, needs to take responsibility and as part of civil society, needs to jointly address this injustice. The argument is that this contribution has particularly envisaged that the church (on all levels) needs to continually reflect on the role that it should play in addressing the challenges of rural education in poverty-stricken South Africa, with regard to its identity, calling and nature.

It is from its identity that the church can and must draw its strength to challenge the social, political and economic systems that continuously turn a blind eye to the plight of the rural education constituency. If the church fails to engage and commit to this calling, dangerous memory will be extinguished, the eschatological memory will be exhausted, and its identity lost. If the church (on all levels) actively commits itself to participate in poverty-stricken rural education, the plight of children in rural schools will not have to be fought in a court of law, but instead, in the trenches of human community. The destination of the journey is achievable - but only if every one of us embarks on this journey with determination, commitment and responsibilities for a better school, and a better society in which we are all included (Mitchell, De Lange \& Xuan Thuy 2008:110). In this way we will all become part of the village that the African proverb alludes to is necessary to raise a child.

\section{Acknowledgements Competing interests}

The author declares that he has no financial or personal relationship(s) that may have inappropriately influenced him in writing this article.

\section{References}

Archambault, I., Janosz, M., Marizot, J. \& Pagani, L., 2009, 'Adolescent behavioral, affective, and cognitive engagement in school: Relationship to dropout', Journal of School of Health 79(9), 408-415. http://dx.doi.org/10.1111/j.17461561.2009.00428.x

Boonzaaier, P.J.V., 2009, 'Baseline Report on multi-grade education in South Africa study commissioned by the Centre for Multi-grade Education (CMGE), Wellington, viewed 28 July 2014, from http://www.google.co.za/url?url=http://www.cmge. co.za/document/download/496\&rct=j\&frm $=1 \& q=\&$ esrc $=s \& s a=U \&$ ei=aibWU6LM BsLXOd-CgYAP\&ved=0CBMQFjAA\&usg=AFQjCNEefzymph5g7z658gAoZROm6Tce SW

Carr, S., 2013, 'Studies examine fetal alcohol syndrome in South Africa', in Medica Xpress, viewed 03 December 2013, from http://medicalxpress.com/news/201308-fetal-alcohol-syndrome-south-africa.html./

Department for Education, United Kingdom, n.d., The role of parents in a child's learning, viewed 06 December 2013, from, http://www.education.gov.uk/ childrenandyoungpeople/families/a00203160/role-of-parents-in-childs-learning

Eccles, J.S. \& Davis-Kean, P.E., 2005, 'Influences of parents' education on their children's educational attainments: the role of parent and child perceptions', London Review of Education 3(3), 191-204.http://dx.doi.org/10.1080/14748460500372309

Fuller, M.L., 2008, 'Poverty: The enemy of children and families', in G. Olsen \& M.L. Fuller (eds.), Home-school relations: Working successfully with parents and families, pp. 273-289, Pearson, Boston.

Hamunyela, M.N., 2008, 'A critical analysis of parental involvement in the education of learners in rural Namibia', PhD dissertation, Department of Education, University of Pretoria. 
Hargreaves, E., 2005, 'Assessment for learning? Thinking outside the (black) box', Cambridge Journal of Education 35(2), 213-224. http://dx.doi. org/10.1080/03057640500146880

Hooghoff, H. \& Joubert, J. (eds.), 2010, 'Multi grade undulation: re-valued', in Proceedings of the Southern African multi-grade education conference 2010, pp. 45-51, Institute for Curriculum Development, Entschede.

Jordaan, V. \& Joubert, J. (n.d.), 'Training of teachers in poor rural areas through a multigrade intervention to achieve millennium development goals: Our experience of using ODL as a tool for building capacity and what lessons can be learned?'in WikiEducator, viewed 10 June 2014, from http://wikieducator.org/ images/f/ff/PID_708.pdf

Joubert, J., 2010, 'Multi-grade teaching in South Africa', in Common Wealth Education Online, viewed 10 June 2014, from http://www.cedol.org/wp-content/ uploads/2012/02/58-62-2010.pdf

Juvane, V., 2007, 'Multi-grade teaching can improve quality of primary education', in Commonwealth Secretariat, viewed 02 December 2013, from http://secretariat. thecommonwealth.org/news/190663/.../090307teaching.htm

'Kaapse skole moet oop bly', Die Burger, 31 July 2013, p. 1.

Lagina, N., 2002, 'Parent-Child communication: Promoting sexually healthy youth', in Advocates for Youth, viewed 06 December 2013, from http://www. advocatesforyouth.org/the-facts-parent-child-communication

Lewis, E., 2011, 'Foetal alcohol syndrome is on the rise, says study', IOL News, viewed 03 December 2013, from http://www.iol.co.za/capeargus/foetal-alcohol-syndromeis-on-the-rise-says-study-1.1149361?ot=inmsa.ArticlePrintPageLayout.ot

Louw, D.J., 2008, Cura Vitae: Illness and the healing of life, LuxVerbi, Cape Town.

Lukhele-Olorunju, P., 2012, 'The challenge of poverty reduction in Africa in the twenty-first century', Africa Insight 41(4), 92-105.

McLoyd, V.C., 1990, 'The impact of economic hardship on black families and children: Psychological distress, parenting, and socio-emotional development', Child Development 61, 311-346. http://dx.doi.org/10.2307/1131096

Metz, J.B., 1980, Faith in history and society: Toward a fundamental Practical Theology, Seabury, New York.
Mitchell, C., De Lange, N. \& XuanThuy, N-T., 2008, “Let's not leave this problem": Exploring inclusive education in rural South Africa', Prospects 38(1), 99-112. $\mathrm{http}: / / \mathrm{dx}$.doi.org/10.1007/s11125-008-9057-y

Neil, P., 2011, 'Approaches to education in rural churches', Rural Theology 8(2), 115-130.

Parsons, T., 1965, 'An outline of the social system,' in T. Parsons, E. Shils, K.D. Naegele \& J.R. Pitts (eds.), Theories of society: Foundations of modern sociological theory, pp. 30-79, The Free Press of Glencoe, Inc., New York.

Ruzive, F.F., 2012, 'Robben Island Primary School - an opportunity to continue a legacy,' South African Rural Educator 2, 57-73.

Ramphele, M. \& Wilson, F., 1989, Uprooting poverty: The South African challenge: Report for the second Carnegie inquiry into poverty and development in Southern Africa, David Philip, Cape Town.

Schore, A., 2002, 'Advances in neuro-psychoanalysis, attachment theory, and trauma research: Implications for self-psychology', Psychoanalytic Inquiry 22, 433-484. http://dx.doi.org/10.1080/07351692209348996

Smit, D.J., 2004, 'Oor die kerk en maatskaplike uitdagings in ons land', Nederduits Gereformeerde Teologiese Tydskrif 45(2), 350-362, suppl.

Terreblanche, S., 2002, A history of inequality in South Africa 1652-2002, University of KwaZulu-Natal Press, Pietermaritzburg.

UNICEF, n.d., Convention on the Rights of the Child: A summary of the right: Article 27, viewed 02 December 2013, from http://www.unicef.org/crc/files/Rights overview.pdf

Van der Merwe, H.M., 2011, 'Education of quality to the poor', Koers - Bulletin for Christian Scholarship 76(4), 771-787. http://dx.doi.org/10.4102/koers.v76i4.420

Van der Ven, J.A., 1993, Ecclesiologie in context, Kok, Kampen.

Waghid, Y., 2002, 'Educational development in rural schools: Exemplifying the persona dimension of community', South African Journal of Education EASA 22(1), 1-5.

Walker, L., (n.d.), 'Influences on children's language development', in Global Post viewed 06 December 2013, from http://everydaylife.globalpost.com/influenceschildrens-language-development-2083.html 